\title{
Rosmarinic Acid Activates AMPK to Inhibit Metastasis of Colorectal Cancer
}

\author{
Yo-Han Hant, Ji-Ye Kee ${ }^{\dagger}$ and Seung-Heon Hong* \\ Department of Oriental Pharmacy, College of Pharmacy, Wonkwang-Oriental Medicines Research Institute, Wonkwang \\ University, Iksan, South Korea
}

\section{OPEN ACCESS}

Edited by:

Thomas Efferth,

Johannes Gutenberg-Universität

Mainz, Germany

Reviewed by:

Rajendra Karki,

St. Jude Children's Research

Hospital, United States

William Chi-Shing Tai,

Hong Kong Polytechnic University,

Hong Kong

*Correspondence:

Seung-Heon Hong

jooklim@wku.ac.kr

tThese authors have contributed equally to this work.

Specialty section:

This article was submitted to

Ethnopharmacology,

a section of the journal

Frontiers in Pharmacology

Received: 08 September 2017

Accepted: 18 January 2018

Published: 05 February 2018

Citation:

Han $Y-H$, Kee J-Y and Hong S-H

(2018) Rosmarinic Acid Activates AMPK to Inhibit Metastasis

of Colorectal Cancer.

Front. Pharmacol. 9:68.

doi: 10.3389/fphar.2018.00068
Rosmarinic acid (RA) has been used as an anti-inflammatory, anti-diabetic, and anticancer agent. Although RA has also been shown to exert an anti-metastatic effect, the mechanism of this effect has not been reported to be associated with AMP-activated protein kinase (AMPK). The aim of this study was to elucidate whether RA could inhibit the metastatic properties of colorectal cancer (CRC) cells via the phosphorylation of AMPK. RA inhibited the proliferation of CRC cells through the induction of cell cycle arrest and apoptosis. In several metastatic phenotypes of CRC cells, RA regulated epithelial-mesenchymal transition (EMT) through the upregulation of an epithelial marker, $\mathrm{E}$-cadherin, and the downregulation of the mesenchymal markers, $\mathrm{N}$-cadherin, snail, twist, vimentin, and slug. Invasion and migration of CRC cells were inhibited and expressions of matrix metalloproteinase (MMP)-2 and MMP-9 were decreased by RA treatment. Adhesion and adhesion molecules such as ICAM-1 and integrin $\beta 1$ expressions were also reduced by RA treatment. In particular, the effects of RA on EMT and MMPs expressions were due to the activation of AMPK. Moreover, RA inhibited lung metastasis of $\mathrm{CRC}$ cells by activating AMPK in mouse model. Collectively, these results proved that RA could be potential therapeutic agent against metastasis of CRC.

Keywords: rosmarinic acid, colorectal cancer, metastasis, EMT, matrix metalloproteinase, AMPK

\section{INTRODUCTION}

Cancer is one of many lethal diseases and shows an imbalance between cell growth and cell death. Colorectal cancer (CRC) is one of the most commonly diagnosed cancers in the world, and approximately half of the patients with CRC exhibit metastatic properties. Metastasis, the spread of cancer to other remote organs, occurs through a complex process, which includes epithelialmesenchymal transition (EMT), cellular adhesion, migration, and invasion (Wang et al., 2014; Feng et al., 2017). At the beginning of metastasis, cancer cells with epithelial traits are spindle shaped and have lost cell-cell junctions. Subsequently, the cancer cells acquire mesenchymal traits, which promote the migration and invasion of cancer cells and circulate through the blood vessels and lymphatic vessels. Finally, circulating cancer cells adhere to the extracellular matrix of secondary cancer sites (Nicolson, 1991; Li et al., 2009).

Advanced CRC mainly spreads to the liver and the lungs; as the current therapeutic approaches, including surgery, chemotherapy, and irradiation, have not been sufficiently effective, many patients with metastatic cancer die (Fidler, 2003; Geng et al., 2017). In particular, when metastasis occurred at remote sites, the 5-year survival rate declined from 90.3 to $12.5 \%$ (Siegel et al., 2014). 
Although various therapeutic strategies have been achieved in cancer-related science and technology, the therapeutic effects of the current treatments are insufficient (Chen et al., 2017). In addition, the treatments are accompanied by significant side effects, such as intestinal mucositis, neuropathic pain, neutropenia, and diarrhea (Hsieh et al., 2016; Yeh et al., 2016; de Alencar et al., 2017). 5-Fluorouracil (5-FU) and capecitabine, which are widely used to treat CRC, result in undesirable side effects. Several studies have been reported that these anti-cancer agents caused myocardial ischemia and cardiotoxicity (Polk et al., $2013,2014)$. Even though many new drugs have been developed to treat CRC, they often showed the unexpected side effects such as genetic alteration and mutation (Aung et al., 2017). To reduce or replace synthetic drugs, natural product or natural productderived compounds have attracted attention (Afrin et al., 2016; Mayzlish-Gati et al., 2017).

Rosmarinic acid (RA) is an abundant phenolic ester found in Prunella vulgaris, which has been used as an oriental medicine (Zimmermann et al., 2011; Chen et al., 2012). Many studies have reported a range of biological effects for $P$. vulgaris and RA, such as anti-inflammatory, anti-diabetes, and anti-cancer activities (Amoah et al., 2016). Recent studies have also elucidated the anti-metastatic effect of RA: Xu et al. (2010a) reported that RA inhibited bone metastasis induced by breast cancer, which was supported in a further study (Xu et al., 2010b), despite the absence of a specific mechanistic study to describe how RA inhibits metastasis.

AMP-activated protein kinase (AMPK) is a heterotrimeric complex that consists of $\alpha, \beta$, and $\gamma$ subunits (Garcia and Shaw, 2017). Numerous roles of AMPK have been reported and the activation of AMPK exerts therapeutic effects in metabolic syndrome, inflammation, and cancer (Li W. et al., 2015; Han et al., 2016). In various cancer cells, the activation of AMPK stimulated the tumor suppressor gene p53, which has been reported to control apoptosis and the cell cycle (Rattan et al., 2005). As activators of AMPK that were not anti-cancer drugs have shown anti-cancer effects in a clinical setting, we investigated whether natural products that could induce the activation of AMPK in cancer cells might yield meaningful anti-cancer activity (Li et al., 2017). We hypothesized that the activation of AMPK was closely related to the RA-mediated antimetastatic effects on CRC cells and confirmed the effects of RA on metastatic CRC cells and the AMPK-related mechanisms.

\section{MATERIALS AND METHODS}

\section{Reagents and Antibodies}

Antibodies against caspase-3, caspase-8, caspase-9, Bcl-xL, phospho-AMPK, AMPK, cyclin D1 and CDK4 were obtained from Cell Signaling Technology, Inc. (Danvers, MA, United States). The antibody to Bcl-2 and RA were purchased from Santa Cruz Biotechnology, Inc. (Santa Cruz, CA, United States). The antibody to GAPDH was obtained from Enzo Life Sciences (Farmingdale, NY, United States), and compound $\mathrm{C}$ (CC) was obtained from MedChem Express (Monmouth Junction, NJ, United States).

\section{Cell Culture}

Murine colon carcinoma colon 26 (CT26) cells were cultured in Dulbecco's Modified Eagle's Medium (DMEM; Thermo Fisher Scientific, Waltham, MA, United States). Human colon carcinoma cell line HCT116 cells were cultured in RPMI1640 (Thermo Fisher Scientific, Waltham, MA, United States). These media were supplemented with $10 \%$ fetal bovine serum (FBS; Thermo Fisher Scientific, Waltham, MA, United States) and $1 \%$ penicillin-streptomycin (Thermo Fisher Scientific, Waltham, $\mathrm{MA}$, United States) at $37^{\circ} \mathrm{C}$ in a $5 \% \mathrm{CO}_{2}$ incubator.

\section{Cell Viability}

Cell proliferation was calculated by using the cell proliferation reagent MTS Kit (Promega Corporation, Madison, WI, United States), as recommended by the manufacturer. Briefly, cells were seeded in 96-well microplates at $3 \times 10^{3}$ cells/well and medium containing various concentrations of RA was added to the wells. After incubation for 24-96 h, the medium was replaced with MTS solution and the absorbance of each well was measured at $490 \mathrm{~nm}$.

\section{Cell Cycle Analysis}

The cell cycle phase was determined by using Muse Cell Cycle Kit in accordance with the manufacturer's instructions (Millipore, Billerica, MA, United States). Briefly, the RA treated cells $\left(1 \times 10^{6}\right.$ cells $/ \mathrm{mL}$ ) were fixed in $70 \%$ fresh ethanol at $-20^{\circ} \mathrm{C}$ for a minimum of $3 \mathrm{~h}$. After the cells were washed in PBS, $200 \mu \mathrm{L}$ of Cell Cycle Reagent was added and reacted in the dark at room temperature for $30 \mathrm{~min}$. The cells were analyzed by Muse Cell Analyzer and the Muse analysis software (Millipore, Billerica, MA, United States).

\section{Real-Time RT-PCR}

Total RNA was isolated from cells by using QIAzol lysis reagent (QIAGEN, Valencia, CA, United States) in accordance with the manufacturer's instructions. First-strand cDNA was prepared from an RNA template ( $2 \mu \mathrm{g}$ ) using the Power cDNA Synthesis Kit (Applied Biosystems, Carlsbad, CA, United States). Reverse transcription was performed at $37^{\circ} \mathrm{C}$ for $60 \mathrm{~min}$ and then at $95^{\circ} \mathrm{C}$ for $5 \mathrm{~min}$. Real-time RT-PCR was performed by using the Power SYBR $^{\circledR}$ Green PCR Master Mix and StepOne Plus ${ }^{\mathrm{TM}}$ Real-time PCR System (Applied Biosystems, Carlsbad, CA, United States). All data were normalized to GAPDH mRNA or $\beta$-actin. The sequences of the primers are summarized in Tables $\mathbf{1}, \mathbf{2}$.

\section{Annexin V Assay}

The annexin $\mathrm{V}$ assay was conducted by using the Muse Annexin $\mathrm{V}$ and dead cell kit (Millipore, Billerica, MA, United States) in accordance with the manufacturer's instructions. Briefly, the RA-treated cells were collected in culture medium $\left(1 \times 10^{6}\right.$ cells $/ \mathrm{mL}$ ). Then, $100 \mu \mathrm{L}$ of cell-containing medium was reacted with $100 \mu \mathrm{L}$ of Muse Annexin V and dead cell reagent in the dark at room temperature for $20 \mathrm{~min}$. The apoptotic cells were measured by using the Muse Cell Analyzer and Muse analysis software (Millipore, Billerica, MA, United States). 
TABLE 1 | Sequences for real-time RT-PCR mouse primers.

\begin{tabular}{|c|c|c|}
\hline Gene & Forward $\left(5^{\prime}-3^{\prime}\right)$ & Reverse $\left(5^{\prime}-3^{\prime}\right)$ \\
\hline E-cadherin & $\begin{array}{l}\text { AATGGCGGCAATGCAATC } \\
\text { CCAAGA }\end{array}$ & $\begin{array}{l}\text { TGCCACAGACCGATT } \\
\text { GTGGAGATA }\end{array}$ \\
\hline $\mathrm{N}$-cadherin & $\begin{array}{l}\text { TGGAGAACCCCATTG } \\
\text { ACATT }\end{array}$ & $\begin{array}{l}\text { TGATCCCTCAGGAAC } \\
\text { TGTCC }\end{array}$ \\
\hline Snail & $\begin{array}{l}\text { TCCAAACCCACTCGGATGT } \\
\text { GAAGA }\end{array}$ & $\begin{array}{l}\text { TTGGTGCTTGTGGAG } \\
\text { CAAGGACAT }\end{array}$ \\
\hline Twist & $\begin{array}{l}\text { AGCTACGCCTTCTCC } \\
\text { GTCT }\end{array}$ & $\begin{array}{l}\text { TCCTTCTCTGGAAACA } \\
\text { ATGACA }\end{array}$ \\
\hline Vimentin & $\begin{array}{l}\text { CGGAAAGTGGAATCCT } \\
\text { TGCA }\end{array}$ & $\begin{array}{l}\text { CACATCGATCTGGAC } \\
\text { ATGCTG }\end{array}$ \\
\hline Slug & $\begin{array}{l}\text { CATTGCCTTGTGTC } \\
\text { TGCA }\end{array}$ & $\begin{array}{l}\text { AGAAAGGCTITCCC } \\
\text { CAGTG }\end{array}$ \\
\hline MMP-2 & $\begin{array}{l}\text { CCCCATGAAGCCTTGT } \\
\text { TTACC }\end{array}$ & $\begin{array}{l}\text { TTGTAGGAGGTGCCC } \\
\text { TGGAA }\end{array}$ \\
\hline MMP-9 & $\begin{array}{l}\text { AGACCAAGGGTACAGC } \\
\text { CTGTTC }\end{array}$ & $\begin{array}{l}\text { GGCACGCTGGAATGA } \\
\text { TCTAAG }\end{array}$ \\
\hline ICAM-1 & $\begin{array}{l}\text { AACAGAATGGTAGACA } \\
\text { GCA }\end{array}$ & $\begin{array}{l}\text { TCCACCGAGTCCTCT } \\
\text { TAG }\end{array}$ \\
\hline Integrin $\beta 1$ & $\begin{array}{l}\text { GGTाCACTाTGCTGGAG } \\
\text { ATGG }\end{array}$ & $\begin{array}{l}\text { CAGTITCTGGACAAG } \\
\text { GTGAGCAATA }\end{array}$ \\
\hline Cyclin D1 & $\begin{array}{l}\text { TAGGCCCTCAGCCTC } \\
\text { ACTC }\end{array}$ & $\begin{array}{l}\text { CCACCCCTGGGATAA } \\
\text { AGCAC }\end{array}$ \\
\hline CDK 4 & $\begin{array}{l}\text { AGAGCTCTTAGCCGAG } \\
\text { CGTA }\end{array}$ & $\begin{array}{l}\text { TTCAGCCACGGGTTC } \\
\text { ATATC }\end{array}$ \\
\hline NLRC3 & $\begin{array}{l}\text { GTCAGCTGCTACAAGTCCG } \\
\text { GGAC }\end{array}$ & $\begin{array}{l}\text { GAGCCTCAGAGTGCT } \\
\text { TCGGTATCC }\end{array}$ \\
\hline GAPDH & $\begin{array}{l}\text { GACATGCCGCCTGGAG } \\
\text { AAAC }\end{array}$ & $\begin{array}{l}\text { AGCCCAGGATGCCCT } \\
\text { TTAGT }\end{array}$ \\
\hline
\end{tabular}

\section{Western Blot Analysis}

HCT116 cells and CT26 $\left(1 \times 10^{6}\right.$ cells/well $)$ were cultured with RA for 24 and $48 \mathrm{~h}$, respectively. The treated cells were washed with PBS and lysed in lysis buffer (iNtRon Biotech, Seoul, South Korea) for $1 \mathrm{~h}$. The cell lysates were centrifuged for $15 \mathrm{~min}$ and the quantity of protein was evaluated by using a bicinchoninic acid protein assay. The cell lysates were mixed with $2 \times$ sample buffer, loaded onto an SDS-polyacrylamide gel, electrophoresed, transferred to a PVDF membrane (Millipore, Billerica, MA, United States). The membranes were divided to target proteins and blocked by $5 \%$ BSA/TBST for $2 \mathrm{~h}$, incubated with primary antibodies overnight at $4^{\circ} \mathrm{C}$, and then incubated with appropriate secondary antibodies (horseradish peroxidaseconjugated anti-rabbit or anti-mouse immunoglobulin G (Dako, Glostrup, Denmark). The secondary antibodies were detected by the application of ECL solution to the membrane (Santa Cruz, CA, United States). Images were obtained by using the FluorChem E system (ProteinSimple, San Jose, CA, United States).

\section{Wound Healing Assay}

CT26 cells and HCT116 cells were seeded into a 6-well plate $\left(2 \times 10^{5}\right.$ cells/well $)$ and allowed to adhere. A wound area was made by using a $200 \mu \mathrm{L}$ pipette tip. After the detached cells were removed, the scratched area was maintained in serum-free medium that contained different concentrations of RA ( 0 and
$200 \mu \mathrm{M})$ and observed at regular intervals between 0 and $48 \mathrm{~h}$. Randomly selected areas were photographed by using a phase contrast microscope (Leica, Wetzlar, Germany) and wound area was calculated by ImageJ software.

\section{Invasion Assay}

The invasion assay was conducted by using BD BioCoat GFR Matrigel invasion chambers (BD Biosciences, San Jose, CA, United States). CT26 and HCT116 cells $\left(5 \times 10^{4}\right.$ cells $)$ were cultured in serum-free DMEM with RA in the upper chamber and $10 \%$ FBS in DMEM in the lower chamber. After incubation, the membrane inserts were washed twice with PBS and fixed in 3.7\% paraformaldehyde in PBS for $5 \mathrm{~min}$. The fixed cells were washed by PBS, incubated with $100 \%$ methanol for $20 \mathrm{~min}$, and stained with Giemsa for $15 \mathrm{~min}$. The inner sides of the chamber were wiped with a cotton swab and the cells were observed by using a microscope (Leica, Wetzlar, Germany) and cells were counted in random areas per insert.

\section{Adhesion Assay}

To conduct the adhesion assay, CT26 and HCT116 cells $\left(3 \times 10^{3}\right.$ cells $)$ were seeded in pre-coated Matrigel 96-well plates and treated with RA for 24 or $48 \mathrm{~h}$. After incubation, the adherent cells were fixed in 10\% formaldehyde for $15 \mathrm{~min}$ and stained with $0.05 \%$ crystal violet solution for $10 \mathrm{~min}$ (Sigma Chemicals, St. Louis, MO, United States). After staining, the

TABLE 2 | Sequences for real-time RT-PCR human primers.

\begin{tabular}{|c|c|c|}
\hline Gene & Forward $\left(5^{\prime}-3^{\prime}\right)$ & Reverse $\left(5^{\prime}-3^{\prime}\right)$ \\
\hline E-cadherin & $\begin{array}{l}\text { GTCAGTTCAGACTC } \\
\text { CAGCCC }\end{array}$ & $\begin{array}{l}\text { AAATTCACTCTGCCC } \\
\text { AGGACG }\end{array}$ \\
\hline N-cadherin & $\begin{array}{l}\text { CTCCATGTGCCGG } \\
\text { ATGAC }\end{array}$ & $\begin{array}{l}\text { CGATTCACCAGAAG } \\
\text { ССTCTAC }\end{array}$ \\
\hline Snail & $\begin{array}{l}\text { ACCACTATGCCGCG } \\
\text { CTCTT }\end{array}$ & $\begin{array}{l}\text { GGTCGTAGGGCTGC } \\
\text { TGGAA }\end{array}$ \\
\hline Twist & $\begin{array}{l}\text { AGCTACGCCTTCTC } \\
\text { GGTCT }\end{array}$ & $\begin{array}{l}\text { CCTTCTCTGGAAACA } \\
\text { ATGACATC }\end{array}$ \\
\hline Vimentin & $\begin{array}{l}\text { TCTACGAGGAGGAGA } \\
\text { TGCGG }\end{array}$ & $\begin{array}{l}\text { GGTCAAGACGTGCCA } \\
\text { GAGAC }\end{array}$ \\
\hline Slug & $\begin{array}{l}\text { TGTTGCAGTGAGGGC } \\
\text { AAGAA }\end{array}$ & $\begin{array}{l}\text { GACCCTGGTTGCTTC } \\
\text { AAGGA }\end{array}$ \\
\hline MMP-2 & $\begin{array}{l}\text { AGAAGGCTGTGTTCT } \\
\text { TTGCAG }\end{array}$ & $\begin{array}{l}\text { AGGCTGGTCAGTG } \\
\text { GCTTG }\end{array}$ \\
\hline MMP-9 & $\begin{array}{l}\text { GAACCAATCTCACC } \\
\text { GACGGG }\end{array}$ & $\begin{array}{l}\text { GCCACCCGAGTGTAA } \\
\text { CCATA }\end{array}$ \\
\hline ICAM-1 & $\begin{array}{l}\text { ATGCCCAGACATCTG } \\
\text { TGTCC }\end{array}$ & $\begin{array}{l}\text { GGGGTCTCTATGC } \\
\text { CCAACAA }\end{array}$ \\
\hline Integrin $\beta 1$ & $\begin{array}{l}\text { AACAGAATGGTAGAC } \\
\text { AGCAT }\end{array}$ & $\begin{array}{l}\text { TCCACCGAGTCCT } \\
\text { CTTAG }\end{array}$ \\
\hline Cyclin D1 & $\begin{array}{l}\text { ATGCCAACСTCCTC } \\
\text { AACGAC }\end{array}$ & $\begin{array}{l}\text { GGCTCTIITCACGG } \\
\text { GCTCC }\end{array}$ \\
\hline CDK 4 & $\begin{array}{l}\text { GTGCAGTCGGTGG } \\
\text { TACCTG }\end{array}$ & $\begin{array}{l}\text { TTCGCTTGTGTGGGT } \\
\text { TAAAA }\end{array}$ \\
\hline NLRC3 & $\begin{array}{l}\text { ATGAGGAAGCAAGAGGTGC } \\
\text { GGACGGGC }\end{array}$ & $\begin{array}{l}\text { TCACATITCAACAGTG } \\
\text { CACGTGGGAGC }\end{array}$ \\
\hline$\beta$-actin & $\begin{array}{l}\text { AGAGCTACGAGCTGC } \\
\text { CTGAC }\end{array}$ & $\begin{array}{l}\text { CGTGGATGACACA } \\
\text { GGACT }\end{array}$ \\
\hline
\end{tabular}


crystal violet solution was removed and the plate was washed by PBS. After the plate was completely dried, adherent cells were observed and counted by using a microscope (Leica, Wetzlar, Germany).

\section{Zymography}

The cells were incubated in 6 -well plates $\left(3 \times 10^{5}\right.$ cells/well $)$ and treated with RA. The culture media from the wells were diluted 1:1 in zymography sample buffer and subjected to electrophoresis on an $8 \%$ SDS-PAGE gel containing gelatin. The electrophoresed proteins were renatured by renaturing buffer (2.5\% Triton X-100 in distilled water, $\mathrm{pH} 7.5$ ) for $30 \mathrm{~min}$ at room temperature and then maintained in developing buffer $(50 \mathrm{mM}$ Tris- $\mathrm{HCl} \mathrm{pH} \mathrm{7.5,} 10 \mathrm{mM} \mathrm{CaCl}_{2}$, and $150 \mathrm{mM} \mathrm{NaCl}$ ) overnight at $37^{\circ} \mathrm{C}$. The activity of MMPs was determined by staining with Coomassie Blue R-250 solution for $30 \mathrm{~min}$, which was detected as white bands. Band intensities were measured using ImageJ software.

\section{Immunofluorescence Staining}

Cells $\left(3 \times 10^{3}\right.$ cells/well) were seeded in an 8 -well chamber slide and treated with RA. After incubation, the cells were fixed in $3.7 \%$ formaldehyde for $15 \mathrm{~min}$ at room temperature and washed with PBS for $5 \mathrm{~min}$. The cells were permeabilized with $0.1 \%$ Triton $\mathrm{X}-100$ in PBS for $10 \mathrm{~min}$ and then maintained in blocking buffer (3\% BSA and $0.1 \%$ Triton X-100 in PBS) for $1 \mathrm{~h}$. After blocking, the 8-well chamber slide was reacted with primary antibodies overnight at $4^{\circ} \mathrm{C}$ in a dark room. The primary antibodies were detected with Alexa 488- and Alexa 568-conjugated secondary antibodies (Thermo Fisher Scientific, Waltham, MA, United States). The slides were washed with PBS, the nuclei were counterstained with DAPI (Sigma Chemicals, St. Louis, MO, United States), and the slides were analyzed by using a Zeiss Observer A1 microscope (Carl Zeiss, Oberkochen, Germany).

\section{Experimental Lung Metastasis Model}

$\mathrm{BALB} / \mathrm{c}$ female mice (4 weeks, 16-18 g) were purchased from Samtako (Osan, Korea) and mice were divided into three groups $(n=7)$, which were control group, RA-treated group and CC + RA-treated group. RA was dissolved in $0.3 \%$ CMC water. To inducing lung metastasis, $\mathrm{BALB} / \mathrm{c}$ mice were inoculated with CT26 $\left(1 \times 10^{5}\right.$ cells $)$ in $200 \mu \mathrm{L}$ of PBS via the lateral tail vein. RA-treated group and $\mathrm{CC}+\mathrm{RA}$-treated group were administrated with an oral injection of RA $(100 \mathrm{mg} / \mathrm{kg} /$ day $)$ every day for 14 days. CC was dissolved in 50\% dimethyl sulfoxide (DMSO) and it was administered by intraperitoneal injection every 3 days until sacrifice. Control group mice were administered with the same volume of water. The mice were sacrificed at 14 days, lung weights were measured to evaluate tumor metastasis. Tumor colonies in the lungs were counted after the lungs were fixed in Bouin's solution (Sigma,
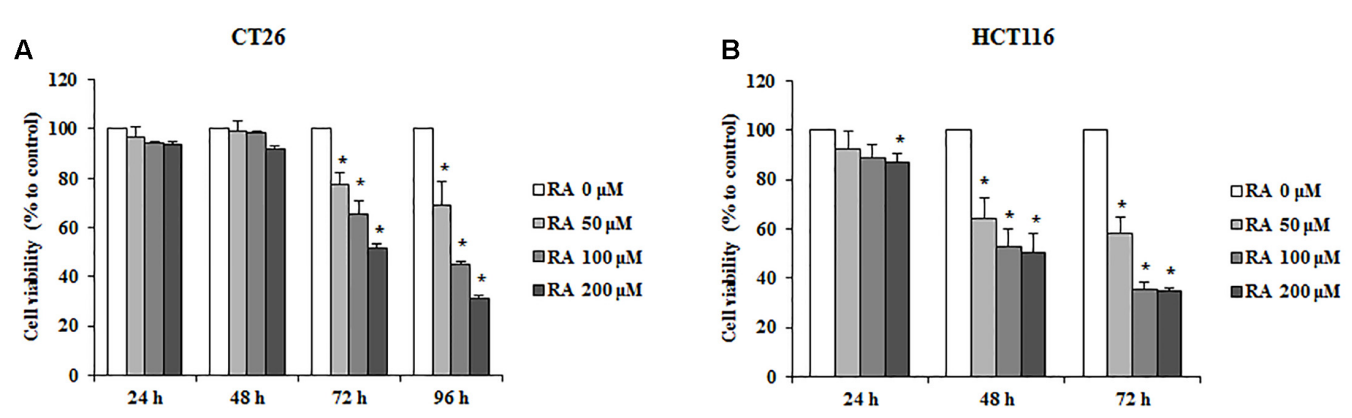

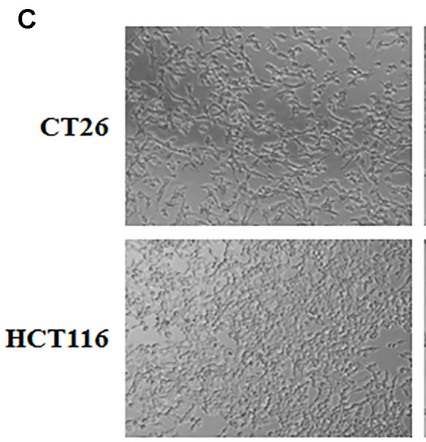

0
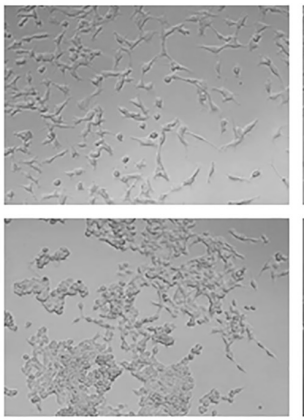

50

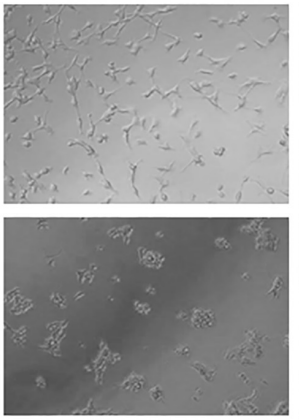

100

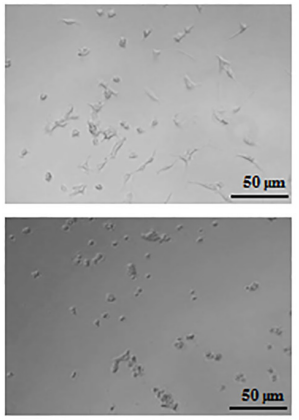

200

$\mathrm{RA}(\mu \mathrm{M})$

FIGURE 1 | Rosmarinic acid (RA) exhibits an anti-proliferative effect on metastatic CRC cells. (A,B) The cell viability of RA-treated CT26 (A) and HCT116 (B) cells. The cells were seeded at a density of $3 \times 10^{3}$ cells/well in 96-well microplates and treated with RA for 24, 48, 72, and $96 \mathrm{~h}$. After treatment with RA, cell viability was measured by using the MTS assay. (C) The morphologies of CT26 and HCT116 cells treated with RA for $96 \mathrm{~h}$ and $72 \mathrm{~h}$, respectively. The images were obtained by using a microscope (200x magnification). The results are expressed as the mean \pm SD. ${ }^{*} p<0.05$ indicates a significant difference from the untreated group. 
St. Louis, MO, United States). Separated serum was assayed by the Seoul Medical Science Institute (Seoul Clinical Laboratories, Seoul, South Korea). The research was conducted in accordance with internationally accepted principles for laboratory animal use and care, as stated in Wonkwang University guidelines (WKU17-52).

\section{Statistical Analyses}

The results are expressed as the mean \pm standard deviation (SD) of three experiments data, and statistical analyses were performed by using Student's $t$-test. All statistical analyses were computed by SPSS statistical analysis software version 11.5 (SPSS Inc., Chicago, IL, United States). Values of $p<0.05$ were considered to represent significant differences.

\section{RESULTS}

\section{RA Inhibits Proliferation of CRC Cells}

To examine whether RA reduced cell survival in metastatic colon cancer cells, CT26 and HCT116 cells were used. The MTS assay was conducted to confirm the cytotoxic effect of RA. As shown in Figures 1A,B, RA treatment inhibited cell proliferation in a time- and concentration-dependent manner. The cytotoxic phenotypes were also observed under a microscope (Figure 1C). To exclude changes in factors due to decreased cell viability, we treated RA $(50,100$, and $200 \mu \mathrm{M})$ for $48 \mathrm{~h}$ in CT26 cells and $24 \mathrm{~h}$ in HCT116 cells, which were not sufficient to affect cell viability.

\section{RA Induces Cell Cycle Arrest of G0/G1 Phase in CRC Cells}

Cells have a self-replicating process known as the cell cycle. As cell cycle arrest suppresses cancer cell growth, it may offer an important strategy for cancer treatment (Bartek and Lukas, 2001). To confirm whether RA induced cell cycle arrest, CT26 and HCT116 cells were treated with RA and analyzed by flow cytometry. Compared with untreated CT26 cells, the percentage of cells in G0/G1 phase increased in RA-treated groups. Additionally, similar tendency was observed in HCT116 cells (Figures 2A,B). These results showed that RA-induced cell cycle arrest in the G0/G1 phase of metastatic CRC cells. To confirm the inhibitory mechanisms, we conducted Western blot and real-time RT-PCR. It was reported that cell cycle arrest in the G0/G1 phase was induced by a decrease in cyclin D-cdks (Pucci et al., 2000). As shown in Figures 2C-F, RA inhibited the protein levels and the mRNA expressions of cyclin D1 and CDK4. These results indicated that RA-mediated G0/G1 phase arrest resulted from decreased cyclin D1 and decreased CDK4.

\section{Effect of RA on Apoptosis of CRC Cells}

As both apoptosis and cell cycle arrest are crucial pathways in the anti-cancer mechanism (Niknejad et al., 2016), we confirmed whether RA could induce apoptosis. To detect the apoptotic cells, we performed an annexin $\mathrm{V}$ assay after the treatment of RA $(0,50,100$, or $200 \mu \mathrm{M})$. As shown in Figures 3A-D, the percentage of apoptotic CT26 and HCT116 cells was significantly increased after treatment with $200 \mu \mathrm{M}$ RA. To further investigate
A

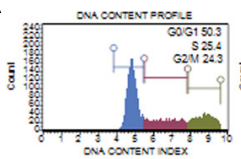

ancontentioex

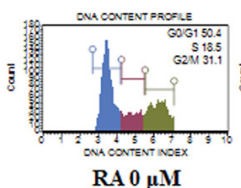

RA $0 \mu \mathrm{M}$

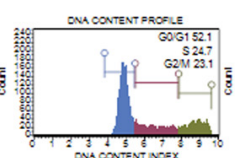

ona content ingex

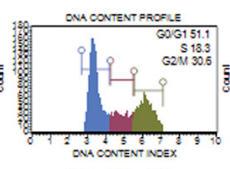

RA $50 \mu M$

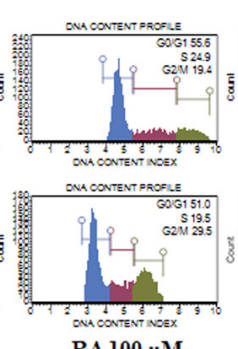

RA $100 \mu \mathrm{M}$

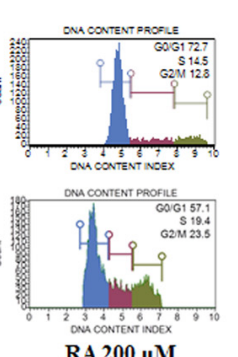

RA $200 \mu M$
B

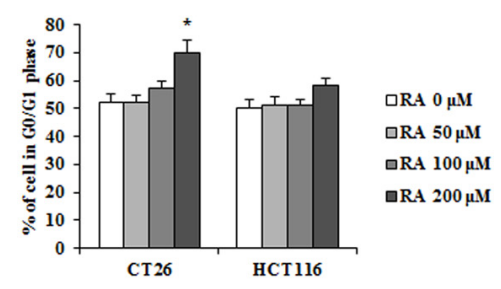

F

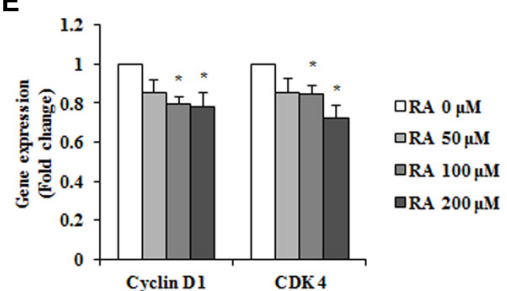

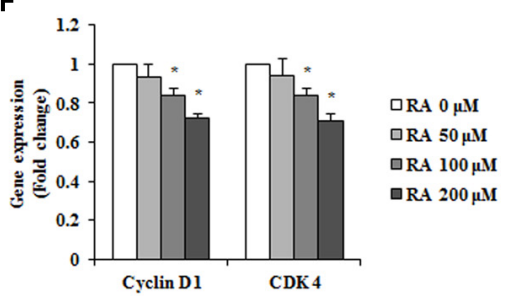

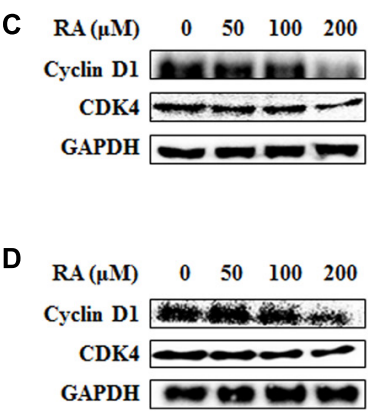

E

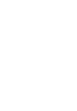

FIGURE 2 | Rosmarinic acid (RA) induces Go/G1 phase arrest in CRC cells. (A) The cell cycle analysis of RA-treated CT26 cells for 48 h (upper part) and RA-treated HCT116 cells for $24 \mathrm{~h}$ (lower part) (B) The population of cells in each cell cycle phase in RA-treated CT26 and HCT116 cells. (C,D) The proteins expression of cyclin D1 and CDK4 in RA-treated CT26 cells for 48 h (C) and RA-treated HCT116 cells for 24 h (D). (E,F) The mRNA expression of cyclin D1 and CDK4 in RA-treated CT26 cells for $48 \mathrm{~h}$ (E) and RA-treated HCT116 cells (F) for $24 \mathrm{~h}$. GAPDH and $\beta$-actin were used as the endogenous control. The results are expressed as the mean $\pm \mathrm{SD}$. ${ }^{*} p<0.05$ indicates a significant difference from the untreated group. 
A

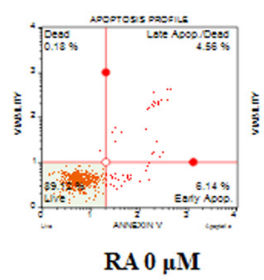

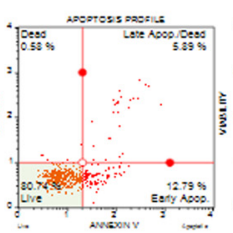

RA $50 \mu \mathrm{M}$

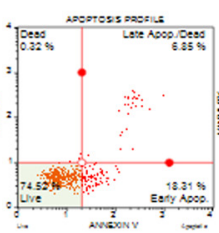

$\mathrm{RA} 100 \mu \mathrm{M}$

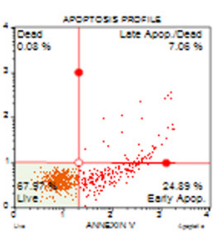

RA $200 \mu \mathrm{M}$

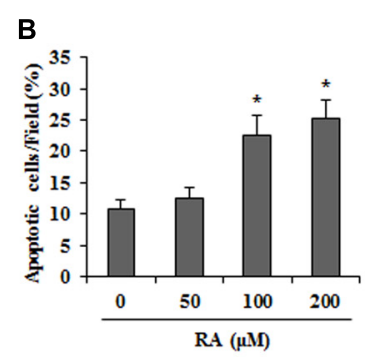

D

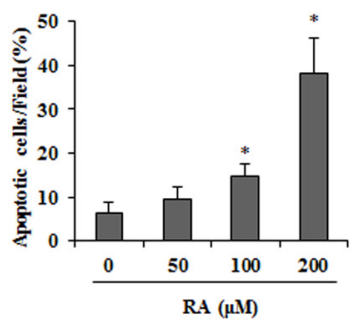

E
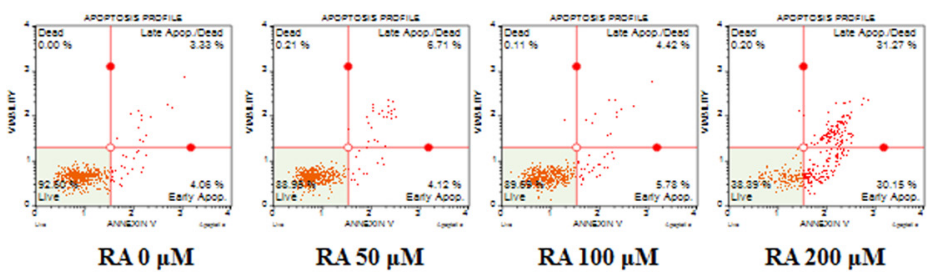

$\mathbf{F}$
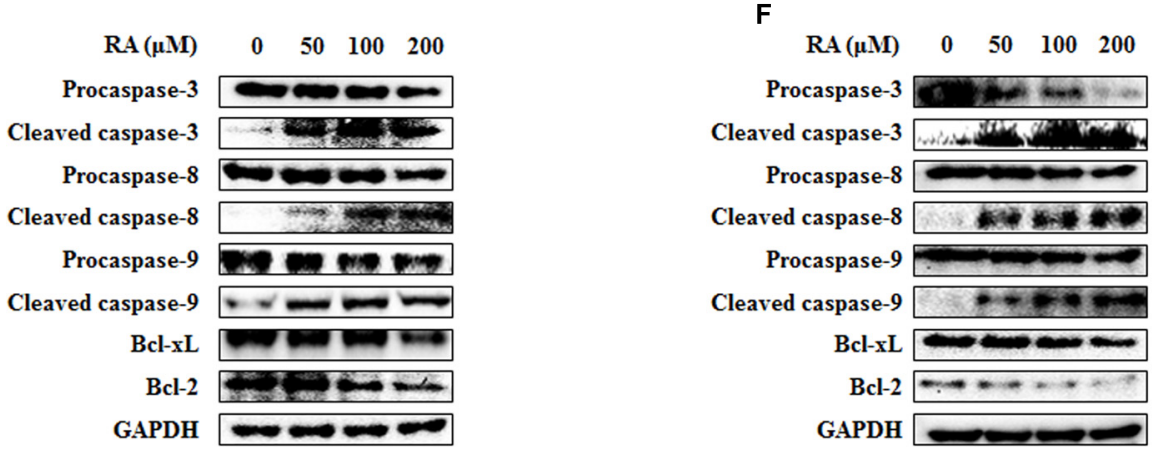

FIGURE 3 | Rosmarinic acid (RA) induces apoptosis of CRC cells via the extrinsic and intrinsic apoptosis pathway. (A) CT26 cells were treated with the indicated concentrations of RA for $48 \mathrm{~h}$ and stained with annexin $\mathrm{V}$ and propidium iodide. (B) The quantification of apoptotic cells. The data indicate the percentage of apoptotic cells after RA treatment. (C) HCT116 cells were treated with the indicated concentrations of RA for $24 \mathrm{~h}$ and stained with annexin $\mathrm{V}$ and propidium iodide. (D) The quantification of apoptotic cells. The data indicate the percentage of apoptotic cells after RA treatment. (E) CT26 cells were treated with RA for $48 \mathrm{~h}$ and a Western blot was conducted to detect the expression of procaspase-3, cleaved caspase-3, procaspase-8, cleaved caspase-8, procaspase-9, cleaved caspase-9, PARP, Bcl-xL, and Bcl-2. (F) HCT116 cells were treated with RA for $24 \mathrm{~h}$ and Western blot was conducted. The expression of GAPDH used as an endogenous control. The results are expressed as the mean \pm SD. ${ }^{*} p<0.05$ indicates a significant difference from the untreated group.

the mechanisms of apoptosis, Western blotting analysis was conducted. As shown in Figures 3E,F, the treatment of CT26 and HCT116 cells with RA reduced the protein levels of procaspase9, Bcl-xL, and Bcl-2, which are related to the intrinsic apoptosis pathway (Ren et al., 2013). Procaspase-3 and procaspase-8, which are related to the extrinsic apoptosis pathway (Fatehchand et al., 2017), were reduced by RA. Continually, cleavage of caspase-3, 8 , and -9 were increased by RA treatment in CT26 and HCT116 cells. These results suggested that RA induced apoptosis via the intrinsic and extrinsic pathways.

\section{RA Regulated EMT of CRC Cells}

For cancer cells to metastasize, the epithelial phenotype has to change to a mesenchymal phenotype; this phenomenon is known as EMT (Sowa et al., 2015). To investigate whether RA could regulate the EMT, we conducted immunofluorescence staining to detect the expression of E-cadherin and N-cadherin. As shown in Figures $\mathbf{4 A , B}$, the expression of E-cadherin, an epithelial marker, was increased, and $\mathrm{N}$-cadherin, a mesenchymal marker, was inhibited in CT26 cells treated with RA. Additionally, the real-time RT-PCR data were consistent with the results of immunofluorescence staining (Figure 4C). Other EMT-related mesenchymal markers, including snail, twist, vimentin, and slug, were inhibited by treatment with RA (Figure 4D). In HCT116 cells, RA also regulated expressions of EMT-related makers to inhibit EMT process (Figures 4E,F).

\section{RA Disrupts the Migration, Invasion, and Adhesion Abilities of CRC Cells}

For cancer cells to metastasize, the cells of primary tumors invade the ECM and migrate to the secondary site. During this process, circulating cells, which survive from the immune system, eventually get attached to the secondary site (Reymond et al., 2013). Therefore, the inhibition of invasion, metastasis, and adhesion could be an important strategy for the prevention of metastasis. As shown in Figure $\mathbf{5 A}$, the treatment of CRC 

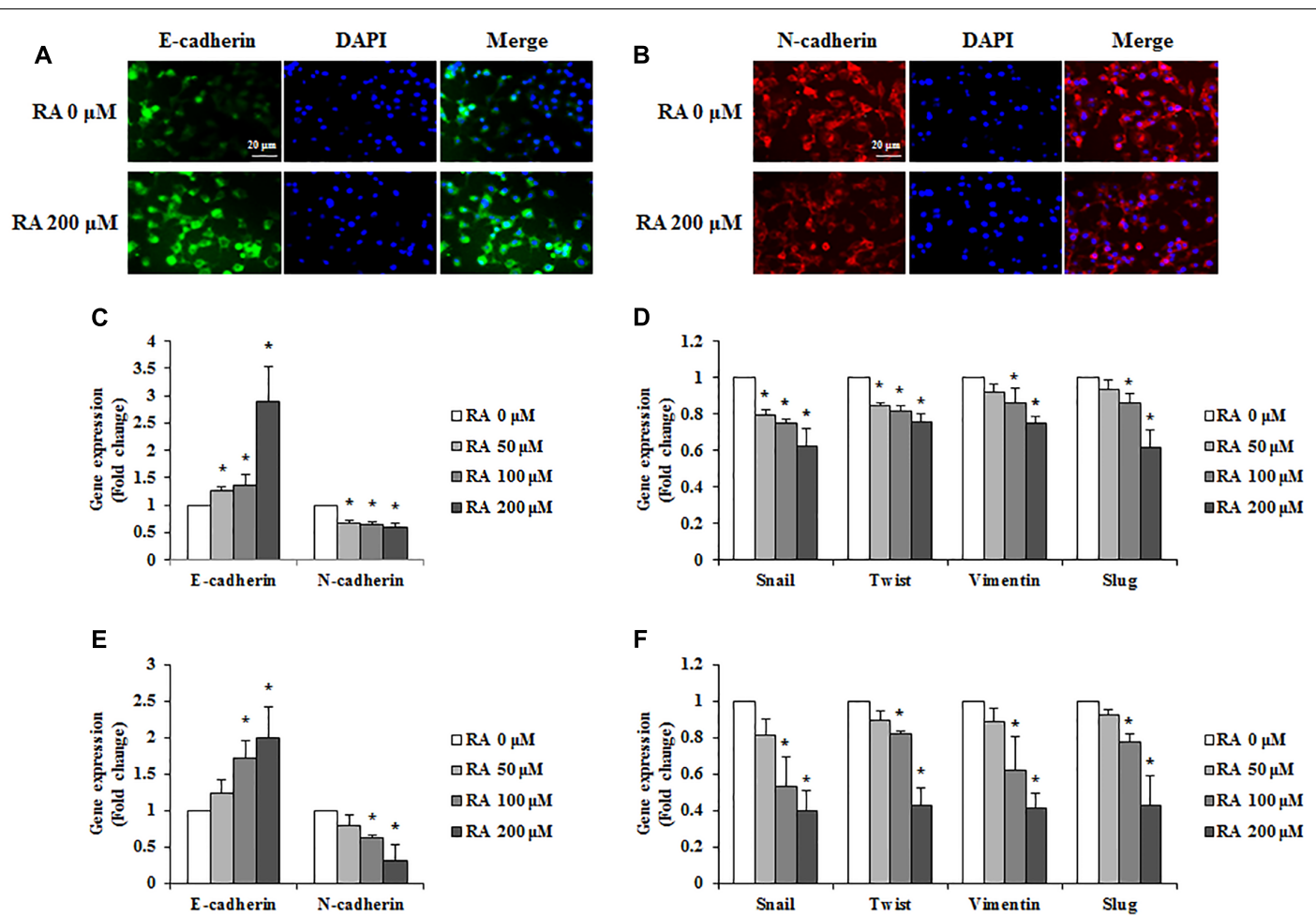

FIGURE 4 | Rosmarinic acid (RA) regulates the EMT of CRC cells. (A,B) Representative immunofluorescence images of E-cadherin (A) and N-cadherin (B) in RA-treated CT26 cells for $48 \mathrm{~h}$. The nuclei were stained with DAPI (blue) and the equivalent phase contrast images were taken by fluorescent microscope. (C,E) The mRNA expression of E-cadherin and N-cadherin in RA-treated CT26 cells (C) and HCT116 cells (E). (D,F) The mRNA expression of snail, twist, vimentin, and slug in RA-treated CT26 cells (D) and HCT116 cells (F). GAPDH and $\beta$-actin were used as the endogenous control. The results are expressed as the mean \pm SD.

${ }^{*} p<0.05$ indicates a significant difference from the untreated group.

cells with RA inhibited invasion, migration, and adhesion. We confirmed the levels of MMP-2 and MMP-9, which promote ECM degradation and induce invasion and migration. To analyze the expression and activities of MMP-2 and MMP-9, real-time RT-PCR and gelatin zymography were conducted. As shown in Figures 5B-D, RA reduced the expression and activities of MMP-2 and MMP-9 in CT26 cells. Moreover, the adhesionrelated factors, ICAM- 1 and integrin $\beta 1$, were decreased by RA treatment (Figures 5C,D). These results suggested that RA could inhibit invasion, migration, and invasion.

\section{RA Inhibits EMT, Invasion, and Migration via AMPK Phosphorylation in CRC Cells}

The phosphorylation of AMPK was associated with better prognosis and survival rate (Baba et al., 2010; Esfahanian et al., 2012) and with inhibition of EMT in lung and breast cancers (Chou et al., 2014; Qu et al., 2014; Lin et al., 2015). Several studies have reported that the activation of AMPK inhibited the expression of MMP-2 and MMP-9, which are crucial factors related to invasion and migration (Morizane et al., 2011). It was also reported that AMPK could regulate ICAM-1 and integrin $\beta 1$ (Ha et al., 2015). First, we confirmed whether RA induced the phosphorylation of AMPK in CRC cells. As shown in Figures 6A, 7A, RA treatment induced AMPK phosphorylation. Next, to elucidate the correlation between
AMPK phosphorylation and the anti-metastatic effect of RA, we pre-incubated the cells with CC, a potent AMPK inhibitor, and then treated RA for $48 \mathrm{~h}$ in CT26 cells and $24 \mathrm{~h}$ in HCT 116 cells. Phosphorylation of AMPK was sufficiently blocked by CC treatment (Figures 6B, 7B). CC pretreatment disrupted the inhibitory effect of RA on the expressions of MMP-2 and MMP-9 in both cell lines. However, the expressions of the adhesion molecules ICAM- 1 and integrin $\beta 1$ were reduced by $\mathrm{RA}$, despite the blocking of AMPK activation (Figures 6C, 7C). The expression of the EMT markers E-cadherin and N-cadherin was not regulated after CC pretreatment and the subsequent RA treatment in CT26 cells (Figures 6D,E). In addition, similar result was shown in HCT116 cells (Figures 7D,E). These results indicated that the anti-metastatic effects of RA on the EMT, invasion, and migration a result of AMPK phosphorylation.

\section{RA Reduces Lung Metastasis of CRC Cells via Activation of AMPK in an Experimental Metastasis Model}

Our study also investigated that whether RA could ameliorate lung metastasis by activating AMPK. As shown in Figures 8A-C, the numbers of pulmonary tumor nodules and lung weights were decreased by oral administration of RA. Moreover, these anti-metastatic effects of RA were ameliorated by CC treatment. 

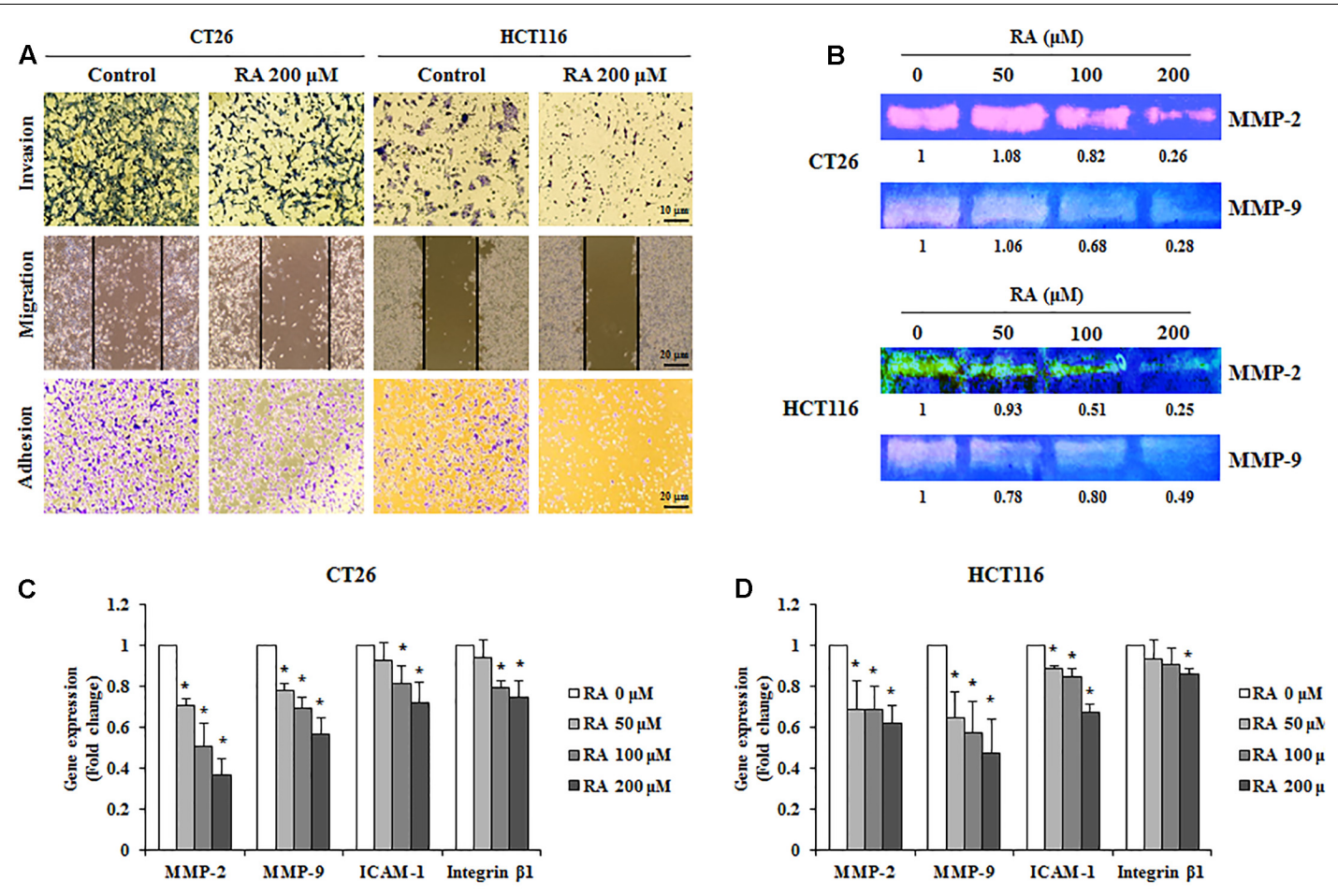

FIGURE 5 | Rosmarinic acid (RA) reduces the migration, invasion, and adhesion of CRC cells and inhibits the expression of related factors. (A) Invasion assay (upper), wound healing assay (middle), and adhesion assay (lower) of RA-treated CT26 and HCT116 cells. After treatment of RA for $48 \mathrm{~h}$ in CT26 cells and $24 \mathrm{~h}$ in HCT116 cells, the images were collected by using a microscope $(200 \times, 100 \times$, and 100x, respectively). (B) The activities of MMP-2 and MMP-9 were determined by gelatin zymography in CT26 cells treated with RA for $48 \mathrm{~h}$ and HCT116 cells treated with RA for $24 \mathrm{~h}$. (C,D) The mRNA expressions of MMP-2, MMP-9, ICAM-1, and Integrin $\beta 1$ in CT2 6 cells treated with RA for $48 \mathrm{~h}$ (C), and HCT116 cells treated with RA for $24 \mathrm{~h}$ (D). The results are expressed as the mean \pm SD. * $p<0.05$ indicates a significant difference from the untreated group.

Compared to the control group, phosphorylation of AMPK was increased in RA-treated group, whereas it was blocked in CC + RA group (Figure 8D). Body weight, an indicator of toxicity, was not reduced by RA administration (Figure 8E). Furthermore, RA did not show the hepatotoxicity and nephrotoxicity (Table 3). These results indicated that RA could inhibit the lung metastasis of CRC cells through AMPK activation.

\section{DISCUSSION}

The main treatments for cancer currently comprise surgery, chemotherapy, and radiation therapy. Although surgery is the most reliable method, it is suitable only for solid tumors. Furthermore, chemotherapy, such as the administration of chemical drugs and radiotherapy, is accompanied by considerable side effects. In severe cases, the cancer treatment itself leads to mortality (Joshi et al., 2009). For these reasons, the bioactive compounds in natural products, oriental medicine, and spices have been studied as substitutes for cancer drugs and to reduce the severity of the side effects (Li et al., 2011).

Rosmarinic acid, which is commonly abundant in Boraginaceae and Lamiaceae, is not only easy to obtain, but can also be ingested as tea or food (Petersen and Simmonds, 2003). It is well known for its anti-inflammatory effects and has been used for the prevention of cancer in folk medicine (Elansary and Mahmoud, 2015). Xu et al. reported that RA inhibits invasion via the oxidation-reduction pathway in LS174T cells, whereas the specific molecular inhibitory mechanism of RA remains unclear ( $\mathrm{Xu}$ et al., 2010b). Furthermore, RA could improve the efficiency of radiation therapy by exerting a radiosensitizing effect on cancer cells (Alcaraz et al., 2014). Various studies focused on AMPK, which is involved in various roles in a wide range of tissues such as liver, muscle and adipose tissues, as a new therapeutic target of cancer (Hardie et al., 2003). In addition, many evidences showed that the AMPK pathway controls the processes of cancer cell migration and invasion (Li N. et al., 2015). However, there was no study on the effects of RA on the CRC via AMPK pathway. Therefore, the study of the AMPK related mechanism will allow RA to be used in an adjuvant chemotherapy or chemotherapy. In the present study, we first confirmed the anti-proliferative effect of RA on the metastatic murine and human CRC cell line, CT26 and HCT116. As expected, treatment with RA inhibited the proliferation of CRC (Figure 1). As the anti-proliferative effect was closely related to cell cycle arrest and apoptosis (Niknejad et al., 2016), we confirmed the changes in the cell cycle of CT26 cells after treatment with RA. RA induced cell cycle arrest through an increase in the percentage of cells in the G0/G1 


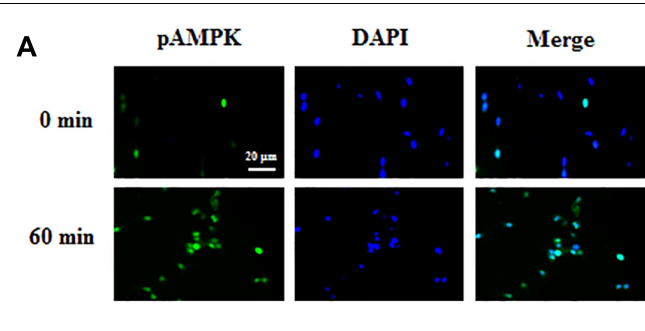

B
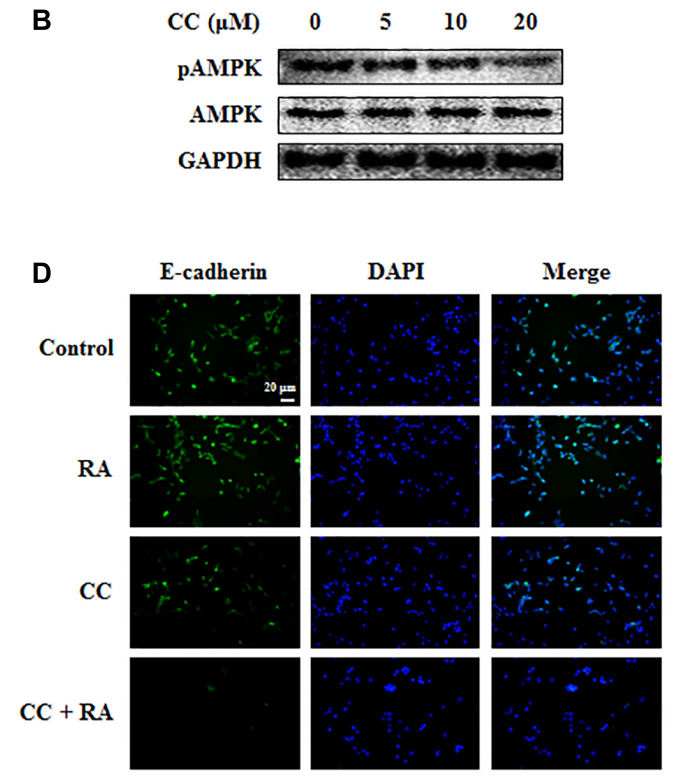
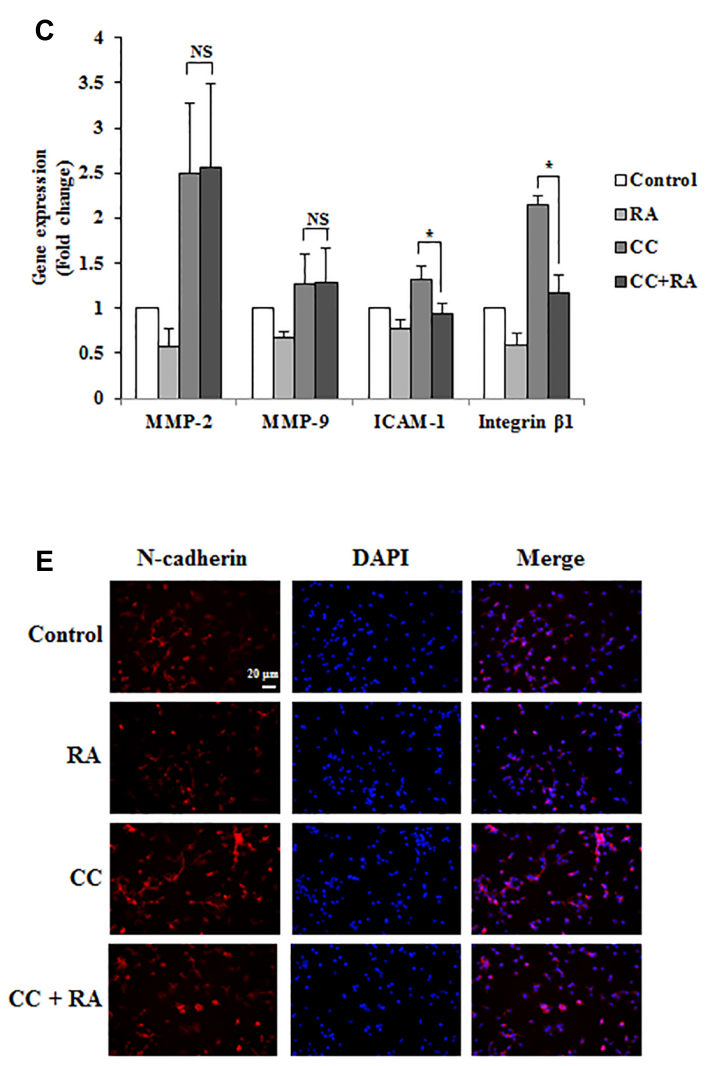

FIGURE 6 | Rosmarinic acid (RA) inhibits the EMT, migration, and invasion through AMPK activation in CT26 cells. (A) Representative immunofluorescence images of phospho-AMPK. The nuclei were stained with DAPI (blue) and equivalent phase contrast images were obtained by fluorescence microscopy. Scale bar $=20 \mu \mathrm{m}$. (B) CT26 cells were treated with CC for $4 \mathrm{~h}$ and detected phosphorylation levels of AMPK. (C) The mRNA expressions of MMP-2, MMP-9, ICAM-1, and integrin $\beta 1$. GAPDH was used as the endogenous control. (D,E) Representative immunofluorescence images of E-cadherin (D) and N-cadherin (E). CC (20 $\mu$ M) was pre-treated for $4 \mathrm{~h}$ and then CT26 cells were treated with RA for $48 \mathrm{~h}$. The nuclei were stained with DAPI (blue) and equivalent phase contrast images were obtained by fluorescence microscopy. Scale bar $=20 \mu \mathrm{m}$. The results are expressed as the mean \pm SD. ${ }^{*} p<0.05$ indicates significant differences from the CC-treated group. ${ }^{N S} p>0.05$ indicates no significant differences from the CC-treated group.

phase (Figures 2A,B). To proceed from the G0/G1 phase to the $\mathrm{S}$ phase, cyclin D1 activated CDK4. As shown in Figures $2 \mathrm{C}-\mathrm{F}$, the treatment with RA decreased the protein and the mRNA expressions of cyclin D1 and CDK4. Thus, our data demonstrated that RA induced G0/G1 phase arrest through the regulation of the expression of cyclin D1 and CDK4.

Apoptosis, which is classified into the extrinsic and intrinsic pathways, is deregulated in cancer cells. The induction of apoptosis is a therapeutic strategy for the treatment of cancer (Hassan et al., 2014). In this study, we confirmed that RA induced apoptosis of CRC cells (Figures 3A-D). To investigate the related mechanisms, RA-regulated protein levels were analyzed. The extrinsic apoptosis pathway is induced by the tumor necrosis factor family. Once this pathway is activated, procaspase- 8 was cleaved to caspase- 8 and then procaspase- 3 was also cleaved to caspase-3, which leads to cell death (Lowe and Lin, 2000; Safa, 2012). As shown in Figures 3E,F, RA induced the cleavage of caspase-3, caspase-8, and caspase-9. In the intrinsic apoptosis pathway, the anti-apoptotic proteins $\mathrm{Bcl}-2$ and $\mathrm{Bcl}-\mathrm{xL}$ exert self-inhibitory action and emit cytochrome c. Cytochrome c induced apoptosis and converted procaspase- 9 to active caspase- 9 (Deveraux et al., 1998; Verhagen et al., 2000). Our data showed that RA downregulated procaspase- $9, \mathrm{Bcl}-\mathrm{xL}$, and $\mathrm{Bcl}-2$ in CRC cells (Figures 3E,F). These results indicated that RA induced apoptosis through the extrinsic and intrinsic apoptosis pathways.

Cancer cells that become detached from the primary tumor circulate, reach distant organs, and then form a secondary tumor. EMT causes cancer cells to lose cellto-cell contacts through an adoption of mesenchymal features, which are required for detachment from the primary tumor (Tian et al., 2016). During this process, epithelial markers, such as E-cadherin, are downregulated, whereas the mesenchymal markers such as $\mathrm{N}$-cadherin, snail, twist, vimentin and slug are upregulated. Therefore, the inhibition of EMT is crucial for the prevention of metastasis. To confirm the expression of E-cadherin 

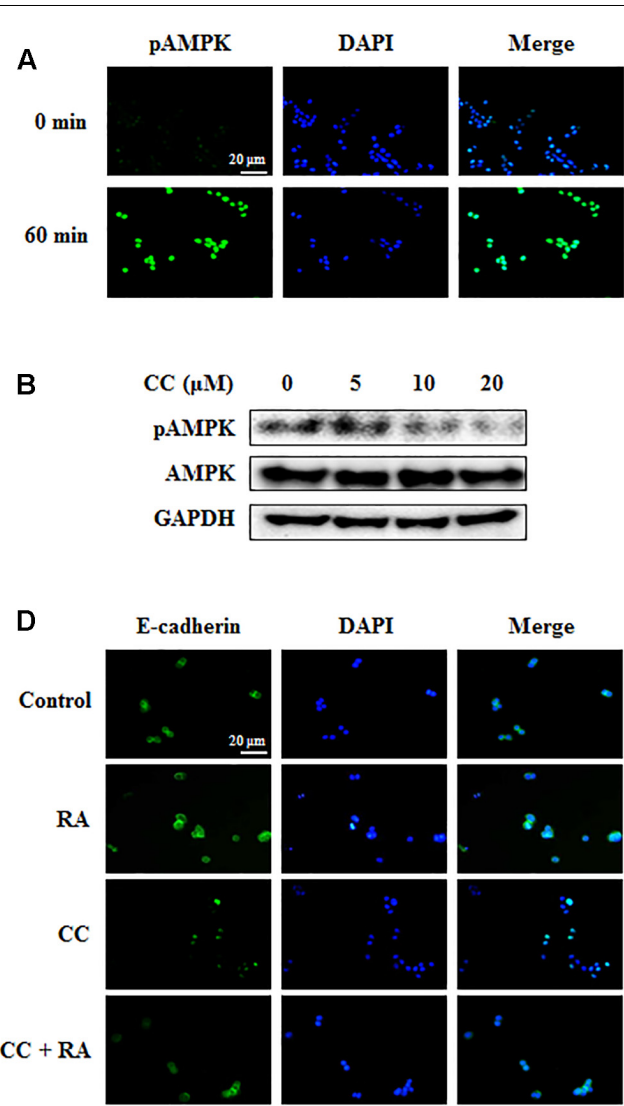
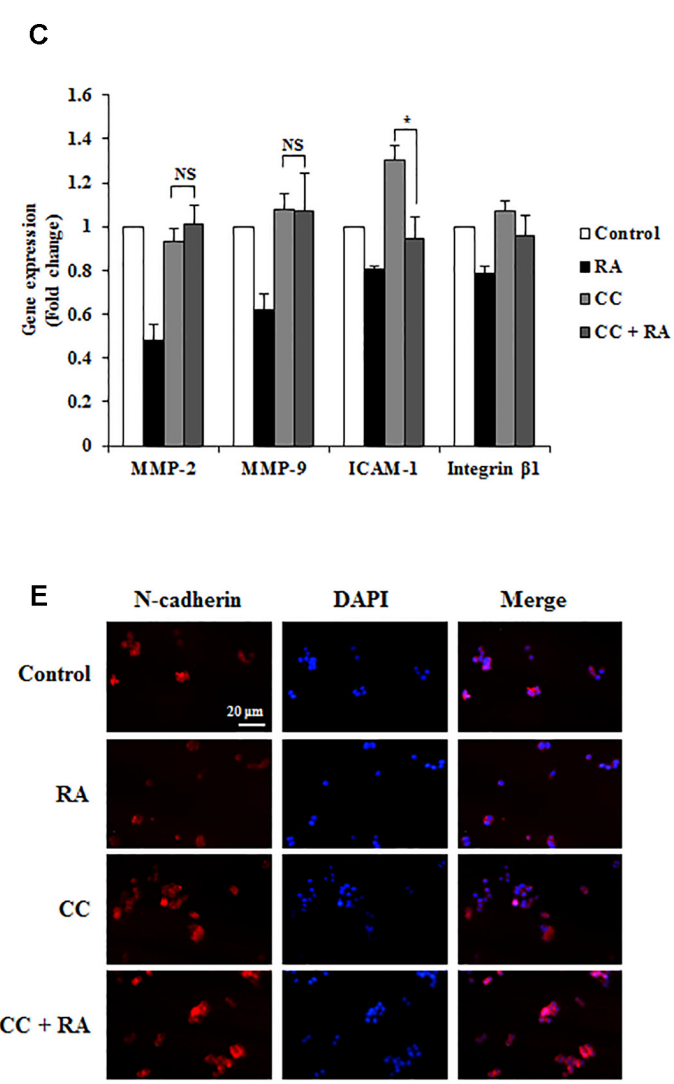

FIGURE 7 | Rosmarinic acid (RA) inhibits the EMT, migration, and invasion through AMPK activation in HCT116 cells. (A) Representative immunofluorescence images of phospho-AMPK. The nuclei were stained with DAPI (blue) and equivalent phase contrast images were obtained by fluorescence microscopy. Scale bar $=20 \mu \mathrm{m}$. (B) HCT116 cells were treated with CC for $4 \mathrm{~h}$ and detected phosphorylation levels of AMPK. (C) The mRNA expression of MMP-2, MMP-9, ICAM-1, and integrin $\beta 1$. GAPDH and $\beta$-actin were used as the endogenous control. (D,E) Representative immunofluorescence images of E-cadherin (D) and $\mathrm{N}$-cadherin (E). $\mathrm{CC}(20 \mu \mathrm{M})$ was pre-treated for $4 \mathrm{~h}$ and then HCT116 cells were treated with RA for $24 \mathrm{~h}$. The nuclei were stained with DAPI (blue) and equivalent phase contrast images were obtained by fluorescence microscopy. Scale bar $=20 \mu \mathrm{m}$. The results are expressed as the mean \pm SD. * $p<0.05$ indicates significant differences from the CC-treated group. ${ }^{N S} p>0.05$ indicates no significant differences from the CC-treated group.

and N-cadherin, we conducted immunofluorescence staining. The treatment of CRC cells with RA increased E-cadherin and decreased $\mathrm{N}$-cadherin (Figures 4A,B). Similar to the immunofluorescence staining results, the mRNA levels of E-cadherin and $\mathrm{N}$-cadherin were regulated by treatment with RA (Figure 4C). Furthermore, mesenchymal markers, including snail, twist, vimentin and slug, were inhibited by treatment with RA (Figure 4D). In addition, EMT-related markers were also regulated by RA treatment in HCT116 cells (Figures 4E,F). These results suggested that RA inhibited the EMT of metastatic CRC cells.

After the EMT occurred, the cancer cells underwent migration, invasion, and adhesion (Ondroušková et al., 2016). Detached cancer cells migrate and invade the extracellular matrix, which is destroyed by MMPs (Huang et al., 2015). Therefore, the inhibition of migration and invasion through the reduction of the expression and activity of MMPs would be a sound strategy for the inhibition of metastasis. RA treatment suppressed invasion (Figure $\mathbf{5 A}$, upper part) and migration
(Figure 5A, middle part). Furthermore, the expression and activity of MMP-2 and MMP-9 were decreased by treatment with RA (Figures 5B-D). The cancer cells that survive in the bloodstream become attached to the secondary site and the adhesion molecules, such as ICAM-1 and integrin $\beta 1$, affect the adhesion process (Weiss and Ward, 1983). Similar to previous results, the adhesion of CT26 and HCT116 cells were suppressed (Figure 5A, lower part) and ICAM- 1 and integrin $\beta 1$, which are adhesion molecules, were also suppressed by treatment with RA (Figures 5C,D).

Next, to elucidate the specific mechanisms of the inhibitory effects of RA, we conducted additional experiments to investigate whether RA could activate AMPK. AMPK was reported to regulate the balance of cell growth, energy homeostasis, type II diabetes, obesity, metabolic disease, and cancer (Kang et al., 2013; Monteverde et al., 2015). Recently, several studies demonstrated that the AMPK pathway suppressed invasion and migration through a reduction in MMPs (Petursson et al., 2013; Li N. et al., 2015). Further, AMPK activation inhibited EMT through the regulation of EMT-related makers and 


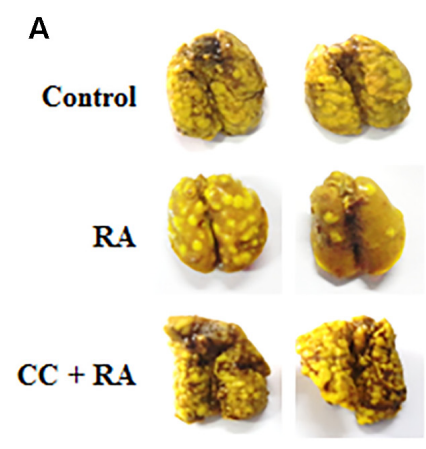

D

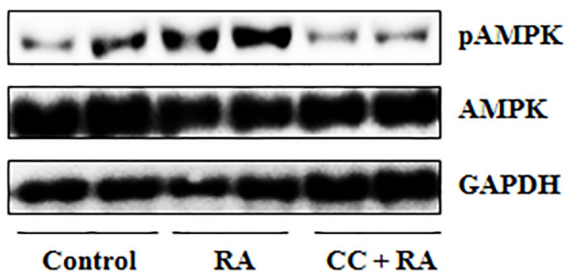

B

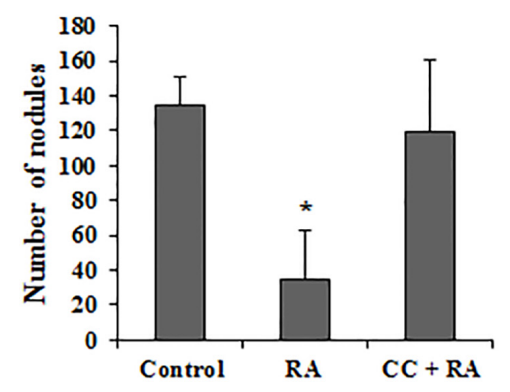

C

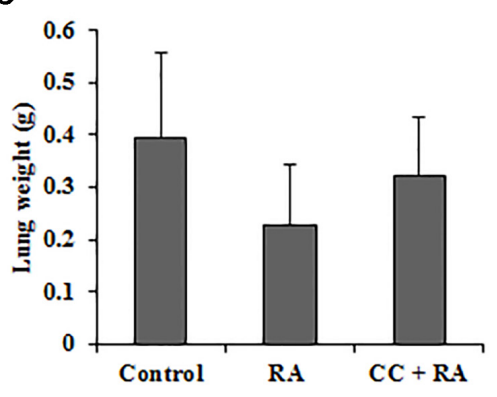

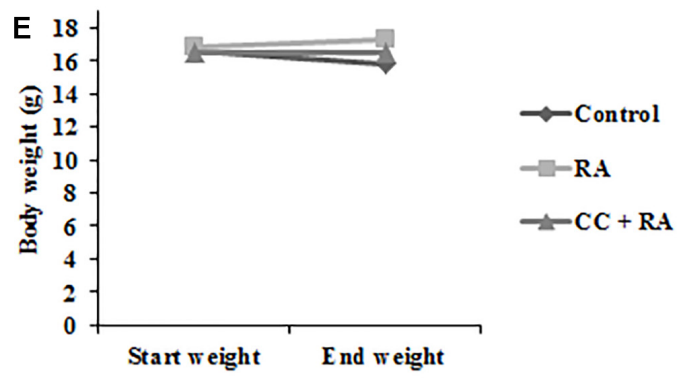

FIGURE 8| Rosmarinic acid (RA) inhibits lung metastasis of CRC cells by activating AMPK. BALB/c mice were intravenously transplanted with $1 \times 10^{5}$ cells of CT26 cells into the tail vein. Then, the mice were divided into three groups $(n=7)$. RA (100 mg/kg) was administered by oral gavage once a day until sacrifice. CC (10 mg/kg) was injected every 3 days. (A) Lungs were stained with Bouin's solution to compare the pattern of tumor nodule formation. (B,C) The number of tumor nodules (B) and lung weights (C). (D) The protein levels of phospho-AMPK were detected in lung tissues. (E) Body weights of experiment groups. The results are expressed as the mean $\pm \mathrm{SD}$. ${ }^{*} p<0.05$ indicates significant differences from the control group.

abolished the attachment of cancer cells through the inhibition of ICAM and integrin (Chen et al., 2011; Lee et al., 2013). In addition, the p53 tumor suppressor gene was directly phosphorylated by AMPK. Therefore, the regulation of AMPK signaling may be a key factor for the treatment of cancer genesis and metastasis (Park et al., 2015). It has been reported that RA could activate AMPK in skeletal muscle (Jayanthy et al., 2017). Thus, we first confirmed whether RA could activate AMPK in CRC cells. As shown in Figures 6A, 7A, RA increased AMPK phosphorylation, and when the activation of AMPK was inhibited by CC pre-treatment, RA was no longer able to regulate the expression of E-cadherin and $\mathrm{N}$-cadherin (Figures 6D,E, 7D,E). Furthermore, MMP-2 and MMP-9 did not appear to be regulated by RA treatment after the inhibition of AMPK (Figures 6C, 7C). Although it appeared that the metastatic traits were exacerbated by pre-treatment with CC, RA could not regulate the EMT and MMPs in when AMPK was inactive. However, RA suppressed adhesion of CRC cells during AMPK inactivation by CC treatment (Figures 6C, 7C). Several studies have reported that NLRC3, which is different pathway from AMPK, inhibited activation of $\mathrm{PI} 3 \mathrm{~K} / \mathrm{AKT} / \mathrm{mTOR}$ axis thereby inhibiting cell proliferation and inducing apoptosis of CRC cells (Karki et al., 2016, 2017). To confirm further whether RA could regulate progression of CRC through other signaling pathway, we also examined gene expression level of NLRC3. However, RA did not regulate the expression of NLRC3 (Supplementary Figure S1). These results suggested that the inhibitory effects of RA on EMT, migration, and invasion ability might be controlled by AMPK activation.

The spontaneous metastasis model is more similar to the clinical cases. However, it took a long time and showed low successful rate (Khanna and Hunter, 2005). For these reasons, we selected an experimental metastasis in vivo model to confirm whether RA could inhibit the metastasis via AMPK pathway. As shown in Figure 8, RA significantly decreased the number of metastatic tumor nodules in lungs by activating AMPK. Although there was no statistical significance, the increase in lung weight due to tumor nodules was inhibited. However, AMPK blocking by CC treatment inhibited the anti-metastatic effects of RA.

Collectively, this study elucidated that RA induced cell death in metastatic CRC cells and inhibited their metastatic properties. RA induced cycle arrest in the G0/G1 phase and apoptosis in CRC cells. It also inhibited

TABLE 3 | Liver and kidney parameters on serum levels in experimental mice.

\begin{tabular}{lcccc}
\hline & AST (IU/L) & ALT (IU/L) & $\begin{array}{c}\text { Creatinine } \\
\text { (mg/dL) }\end{array}$ & $\begin{array}{c}\text { BUN } \\
\text { (mg/dL) }\end{array}$ \\
\hline Control & $183.00 \pm 36.54$ & $39.00 \pm 11.20$ & $0.10 \pm 0.02$ & $22.60 \pm 1.82$ \\
RA & $119.40 \pm 36.85$ & $36.40 \pm 12.74$ & $0.10 \pm 0.03$ & $22.74 \pm 3.30$ \\
RA + CC & $141.20 \pm 51.38$ & $36.60 \pm 6.02$ & $0.12 \pm 0.04$ & $23.50 \pm 3.70$
\end{tabular}


metastatic abilities of CRC cells including EMT, migration, and invasion through activation of AMPK. The in vivo experiment proved that RA could reduce lung metastasis by activating AMPK. Based on our results, RA may be a natural therapeutic drug for the treatment of colon cancer and metastasis.

\section{AUTHOR CONTRIBUTIONS}

Y-HH, J-YK, and S-HH designed the experiments and wrote the manuscript. Y-HH performed the experiments and analyzed the data. S-HH supervised all the experiments and analyses.

\section{REFERENCES}

Afrin, S., Giampieri, F., Gasparrini, M., Forbes-Hernandez, T. Y., Varela-López, A., and Quiles, J. L. (2016). Chemopreventive and therapeutic effects of edible berries: a focus on colon cancer prevention and treatment. Molecules 30:169. doi: 10.3390/molecules21020169

Alcaraz, M., Alcaraz-Saura, M., Achel, D. G., Olivares, A., López-Morata, J. A., and Castillo, J. (2014). Radiosensitizing effect of rosmarinic acid in metastatic melanoma B16F10 cells. Anticancer Res. 34, 1913-1921.

Amoah, S. K., Sandjo, L. P., Kratz, J. M., and Biavatti, M. W. (2016). Rosmarinic acid-pharmaceutical and clinical aspects. Planta Med. 82, 388-406. doi: $10.1055 /$ s-0035-1568274

Aung, T. N., Qu, Z., Kortschak, R. D., and Adelson, D. L. (2017). Understanding the effectiveness of natural compound mixtures in cancer through their molecular mode of action. Int. J. Mol. Sci. 17:E656. doi: 10.3390/ijms180 30656

Baba, Y., Nosho, K., Shima, K., Meyerhardt, J. A., Chan, A. T., Engelman, J. A., et al. (2010). Prognostic significance of AMP-activated protein kinase expression and modifying effect of MAPK3/1 in colorectal cancer. Br. J. Cancer 28, 1025-1033. doi: $10.1038 /$ sj.bjc.6605846

Bartek, J., and Lukas, J. (2001). Pathways governing G1/S transition and their response to DNA damage. FEBS Lett. 16, 117-122. doi: 10.1016/S0014-5793(01) 02114-7

Chen, H., Xiao, Q., Hu, Y., Chen, L., Jiang, K., Tang, Y., et al. (2017). ANGPTL1 attenuates colorectal cancer metastasis by up-regulating microRNA-138. J. Exp. Clin. Cancer Res. 12:78. doi: 10.1186/s13046-0170548-7

Chen, Y., Zhu, Z., Guo, Q., Zhang, L., and Zhang, X. (2012). Variation in concentrations of major bioactive compounds in Prunella vulgaris L. related to plant parts and phenological stages. Biol. Res. 45, 171-175. doi: 10.4067/S071697602012000200009

Chen, Y. C., Lu, P. H., Hsu, J. L., Yu, C. C., and Guh, J. H. (2011). ICAM-1 and AMPK regulate cell detachment and apoptosis by N-methyl-N'-nitro-N-nitrosoguanidine, a widely spread environmental chemical, in human hormone-refractory prostate cancers. Toxicol. Appl. Pharmacol. 257, 412-419. doi: 10.1016/j.taap.2011. 09.025

Chou, C. C., Lee, K. H., Lai, I. L., Wang, D., Mo, X., Kulp, S. K., et al. (2014). AMPK reverses the mesenchymal phenotype of cancer cells by targeting the Akt-MDM2-Foxo3a signaling axis. Cancer Res. 74, 4783-4795. doi: 10.1158/ 0008-5472.CAN-14-0135

de Alencar, N. M., da Silveira Bitencourt, F., de Figueiredo, I. S., Luz, P. B., Lima-Júnior, R. C., Aragão, K. S., et al. (2017). Side-effects of irinotecan (cpt-11), the clinically used drug for colon cancer therapy, are eliminated in experimental animals treated with latex proteins from Calotropis procera (Apocynaceae). Phytother. Res. 31, 312-320. doi: 10.1002/ptr. 5752

Deveraux, Q. L., Roy, N., Stennicke, H. R., Van Arsdale, T., Zhou, Q., Srinivasula, S. M., et al. (1998). IAPs block apoptotic events induced by caspase- 8 and cytochrome c by direct inhibition of distinct caspases. EMBO J. 17, 2215-2223. doi: $10.1093 / \mathrm{emboj} / 17.8 .2215$

\section{FUNDING}

This study was supported by a National Research Foundation of Korea (NRF) grant funded by the Korea government (MSIP) (No. NRF-2015R1C1A1A02036733 and NRF2016R1A2B2013921).

\section{SUPPLEMENTARY MATERIAL}

The Supplementary Material for this article can be found online at: https://www.frontiersin.org/articles/10.3389/fphar. 2018.00068/full\#supplementary-material

Elansary, H. O., and Mahmoud, E. A. (2015). Egyptian herbal tea infusions' antioxidants and their antiproliferative and cytotoxic activities against cancer cells. Nat. Prod. Res. 29, 474-479. doi: 10.1080/14786419.2014. 951354

Esfahanian, N., Shakiba, Y., Nikbin, B., Soraya, H., Maleki-Dizaji, N., GhaziKhansari, M., et al. (2012). Effect of metformin on the proliferation, migration, and MMP-2 and -9 expression of human umbilical vein endothelial cells. Mol. Med. Rep. 5, 1068-1074.doi:10.3892/mmr. 2012.753

Fatehchand, K., Santhanam, R., Shen, B., Erickson, E. L., Gautam, S., Elavazhagan, S., et al. (2017). Active hexose-correlated compound enhances extrinsic-pathway-mediated apoptosis of acute myeloid leukemic cells. PLOS ONE 20:e0181729. doi:10.1371/journal.pone. 0181729

Feng, H. T., Zhao, W. W., Lu, J. J., Wang, Y. T., and Chen, X. P. (2017) Hypaconitine inhibits TGF- $\beta 1$-induced epithelial-mesenchymal transition and suppresses adhesion, migration, and invasion of lung cancer A549 cells. Chin. J. Nat. Med. 15, 427-435. doi:10.1016/S1875-5364(17) 30064-X

Fidler, I. J. (2003). The pathogenesis of cancer metastasis: the 'seed and soil' hypothesis revisited. Nat. Rev. Cancer 3, 453-458. doi: 10.1038/nrc1098

Garcia, D., and Shaw, R. J. (2017). AMPK: mechanisms of cellular energy sensing and restoration of metabolic balance. Mol. Cell 15, 789-800. doi: 10.1016/j. molcel.2017.05.032

Geng, F., Wang, Z., Yin, H., Yu, J., and Cao, B. (2017). Molecular targeted drugs and treatment of colorectal cancer: recent progress and future perspectives. Cancer Biother. Radiopharm. 32, 149-160. doi: 10.1089/cbr.2017. 2210

Ha, B. G., Park, J. E., Cho, H. J., Lim, Y. B., and Shon, Y. H. (2015). Inhibitory effects of proton beam irradiation on integrin expression and signaling pathway in human colon carcinoma HT29 cells. Int. J. Oncol. 46, 2621-2628. doi: 10.3892/ijo.2015.2942

Han, Y. H., Kee, J. Y., Park, J., Kim, H. L., Jeong, M. Y., and Kim, D. S. (2016). Arctigenin inhibits adipogenesis by inducing AMPK activation and reduces weight gain in high-fat diet-induced obese mice. J. Cell. Biochem. 117, 2067-2077. doi: 10.1002/jcb.25509

Hardie, D. G., Scott, J. W., Pan, D. A., and Hudson, E. R. (2003). Management of cellular energy by the AMP-activated protein kinase system. FEBS Lett. 546, 113-120. doi: 10.1016/S0014-5793(03)00560-X

Hassan, M., Watari, H., AbuAlmaaty, A., Ohba, Y., and Sakuragi, N. (2014). Apoptosis and molecular targeting therapy in cancer. Biomed Res. Int. 2014:150845. doi: 10.1155/2014/150845

Hsieh, Y. L., Chou, L. W., Hong, S. F., Chang, F. C., Tseng, S. W., Huang, C. C., et al. (2016). Laser acupuncture attenuates oxaliplatin-induced peripheral neuropathy in patients with gastrointestinal cancer: a pilot prospective cohort study. Acupunct. Med. 34, 398-405. doi: 10.1136/acupmed-2016011112

Huang, Y. L., Chu, Y. L., Ho, C. T., Chung, J. G., Lai, C. I., Su, Y. C., et al. (2015). Antcin K, an active triterpenoid from the fruiting bodies of basswood-cultivated antrodia cinnamomea, inhibits metastasis via suppression of integrin-mediated adhesion, migration, and invasion in 
human hepatoma cells. J. Agric. Food Chem. 63, 4561-4569. doi: 10.1021/jf50 59304

Jayanthy, G., Roshana Devi, V., Ilango, K., and Subramanian, S. P. (2017). Rosmarinic acid mediates mitochondrial biogenesis in insulin resistant skeletal muscle through activation of AMPK. J. Cell. Biochem. 118, 1839-1848. doi: $10.1002 / j c b .25869$

Joshi, B., Wang, X., Banerjee, S., Tian, H., Matzavinos, A., and Chaplain, M. A. (2009). On immunotherapies and cancer vaccination protocols: a mathematical modelling approach. J. Theor. Biol. 259, 820-827. doi: 10.1016/j.jtbi.2009. 05.001

Kang, S. W., Kang, S. I., Shin, H. S., Yoon, S. A., Kim, J. H., Ko, H. C., et al. (2013). Sasa quelpaertensis Nakai extract and its constituent p-coumaric acid inhibit adipogenesis in 3T3-L1 cells through activation of the AMPK pathway. Food Chem. Toxicol. 59, 380-385. doi: 10.1016/j.fct.2013. 06.033

Karki, R., Malireddi, R. K. S., Zhu, Q., and Kanneganti, T. D. (2017). NLRC3 regulates cellular proliferation and apoptosis to attenuate the development of colorectal cancer. Cell Cycle 16, 1243-1251. doi: 10.1080/15384101.2017. 1317414

Karki, R., Man, S. M., Malireddi, R. K., Kesavardhana, S., Zhu, Q., Burton, A. R., et al. (2016). NLRC3 is an inhibitory sensor of PI3K-mTOR pathways in cancer. Nature doi: 10.1038/nature20597 [Epub ahead of print].

Khanna, C., and Hunter, K. (2005). Modeling metastasis in vivo. Carcinogenesis 26, 513-523. doi: 10.1093/carcin/bgh261

Lee, J. H., Kim, J. H., Kim, J. S., Chang, J. W., Kim, S. B., Park, J. S., et al. (2013). AMP-activated protein kinase inhibits TGF- $\beta$-, angiotensin II-, aldosterone-, high glucose-, and albumin-induced epithelial-mesenchymal transition. Am. J. Physiol. Renal Physiol. 15, F686-F697. doi: 10.1152/ajprenal.00148. 2012

Li, J., Zhong, L., Wang, F., and Zhu, H. (2017). Dissecting the role of AMPactivated protein kinase in human diseases. Acta Pharm. Sin. B 7, 249-259. doi: 10.1016/j.apsb.2016.12.003

Li, M., Threadgill, M. D., Wang, Y., Cai, L., and Lin, X. (2009). Poly (ADP-ribose) polymerase inhibition down-regulates expression of metastasis-related genes in CT26 colon carcinoma cells. Pathobiology 76, 108-116. doi: 10.1159/0002 09388

Li, N., Huang, D., Lu, N., and Luo, L. (2015). Role of the LKB1/AMPK pathway in tumor invasion and metastasis of cancer cells (Review). Oncol. Rep. 34, 2821-2826. doi: 10.3892/or.2015.4288

Li, W., Saud, S. M., Young, M. R., Chen, G., and Hua, B. (2015). Targeting AMPK for cancer prevention and treatment. Oncotarget 6, 7365-7378. doi: 10.18632/ oncotarget.3629

Li, Y., Wicha, M. S., Schwartz, S. J., and Sun, D. (2011). Implications of cancer stem cell theory for cancer chemoprevention by natural dietary compounds. J. Nutr. Biochem. 22, 799-806. doi: 10.1016/j.jnutbio.2010. 11.001

Lin, H., Li, N., He, H., Ying, Y., Sunkara, S., Luo, L., et al. (2015). AMPK inhibits the stimulatory effects of TGF- $\beta$ on Smad2/3 activity, cell migration, and epithelialto-mesenchymal transition. Mol. Pharmacol. 88, 1062-1071. doi: 10.1124/mol. 115.099549

Lowe, S. W., and Lin, A. W. (2000). Apoptosis in cancer. Carcinogenesis 21, 485-495. doi: 10.1093/carcin/21.3.485

Mayzlish-Gati, E., Fridlender, M., Nallathambi, R., Selvaraj, G., Nadarajan, S., and Koltai, H. (2017). Review on anti-cancer activity in wild plants of the Middle East. Curr. Med. Chem. doi: 10.2174/0929867324666170705113129 [Epub ahead of print].

Monteverde, T., Muthalagu, N., Port, J., and Murphy, D. J. (2015). Evidence of cancer-promoting roles for AMPK and related kinases. FEBS J. 282, 4658-4671. doi: $10.1111 /$ febs.13534

Morizane, Y., Thanos, A., Takeuchi, K., Murakami, Y., Kayama, M., Trichonas, G., et al. (2011). AMP-activated protein kinase suppresses matrix metalloproteinase-9 expression in mouse embryonic fibroblasts. J. Biol. Chem. 6, 16030-16038. doi: 10.1074/jbc.M110.199398

Nicolson, G. L. (1991). Molecular mechanisms of cancer metastasis: tumor and host properties and the role of oncogenes and suppressor genes. Curr. Opin. Oncol. 3, 75-92. doi: 10.1097/00001622-199102000-00012

Niknejad, H., Yazdanpanah, G., and Ahmadiani, A. (2016). Induction of apoptosis, stimulation of cell-cycle arrest and inhibition of angiogenesis make human amnion-derived cells promising sources for cell therapy of cancer. Cell Tissue Res. 363, 599-608. doi: 10.1007/s00441-0162364-3

Ondroušková, E., Sommerová, L., and Hrstka, R. (2016). Multistep process of establishing carcinoma metastases. Klin. Onkol. 29, 12-17. doi: 10.14735/ amko20164S12

Park, S., Choi, S. K., Choi, Y., and Moon, H. S. (2015). AMPK/p53 axis is essential for $\alpha$-lipoic acid-regulated metastasis in human and mouse colon cancer cells. J. Investig. Med. 63, 882-885. doi: 10.1097/JIM.0000000000 000233

Petersen, M., and Simmonds, M. S. (2003). Rosmarinic acid. Phytochemistry 62, 121-125. doi: 10.1016/S0031-9422(02)00513-7

Petursson, F., Husa, M., June, R., Lotz, M., Terkeltaub, R., and Liu-Bryan, R. (2013). Linked decreases in liver kinase B1 and AMP-activated protein kinase activity modulate matrix catabolic responses to biomechanical injury in chondrocytes. Arthritis Res. Ther. 15:R77. doi: 10.1186/ar4254

Polk, A., Vaage-Nilsen, M., Vistisen, K., and Nielsen, D. L. (2013). Cardiotoxicity in cancer patients treated with 5-fluorouracil or capecitabine: a systematic review of incidence, manifestations and predisposing factors. Cancer Treat. Rev. 39, 974-984. doi: 10.1016/j.ctrv.2013.03.005

Polk, A., Vistisen, K., Vaage-Nilsen, M., and Nielsen, D. L. (2014). A systematic review of the pathophysiology of 5-fluorouracil-induced cardiotoxicity. $B M C$ Pharmacol. Toxicol. 4:47. doi: 10.1186/2050-6511-15-47

Pucci, B., Kasten, M., and Giordano, A. (2000). Cell cycle and apoptosis. Neoplasia 2, 291-299. doi: 10.1038/sj.neo.7900101

Qu, C., Zhang, W., Zheng, G., Zhang, Z., Yin, J., and He, Z. (2014). Metformin reverses multidrug resistance and epithelial-mesenchymal transition (EMT) via activating AMP-activated protein kinase (AMPK) in human breast cancer cells. Mol. Cell. Biochem. 386, 63-71. doi: 10.1007/s11010-0131845 -x

Rattan, R., Giri, S., Singh, A. K., and Singh, I. (2005). 5-Aminoimidazole-4carboxamide-1-beta-D-ribofuranoside inhibits cancer cell proliferation in vitro and in vivo via AMP-activated protein kinase. J. Biol. Chem. 280, 39582-39593. doi: $10.1074 /$ jbc.M507443200

Ren, X., Zhang, Y., Li, C., Wang, H., Jiang, Z., Zhang, Z., et al. (2013). Enhancement of baicalin by hexamethylene bisacetamide on the induction of apoptosis contributes to simultaneous activation of the intrinsic and extrinsic apoptotic pathways in human leukemia cells. Oncol. Rep. 30, 2071-2080. doi: 10.3892/or. 2013.2684

Reymond, N., d'Água, B. B., and Ridley, A. J. (2013). Crossing the endothelial barrier during metastasis. Nat. Rev. Cancer 13, 858-870. doi: 10.1038/nrc3628

Safa, A. R. (2012). c-FLIP, a master anti-apoptotic regulator. Exp. Oncol. 34, $176-184$.

Siegel, R., Desantis, C., and Jemal, A. (2014). Colorectal cancer statistics, 2014. CA Cancer J. Clin. 64, 104-117. doi: 10.3322/caac.21220

Sowa, T., Menju, T., Sonobe, M., Nakanishi, T., Shikuma, K., Imamura, N., et al. (2015). Association between epithelial-mesenchymal transition and cancer stemness and their effect on the prognosis of lung adenocarcinoma. Cancer Med. 4, 1853-1862. doi: 10.1002/cam4.556

Tian, L., Shen, D., Li, X., Shan, X., Wang, X., Yan, Q., et al. (2016). Ginsenoside Rg3 inhibits epithelial-mesenchymal transition (EMT) and invasion of lung cancer by down-regulating FUT4. Oncotarget 7, 1619-1632. doi: 10.18632/oncotarget. 6451

Verhagen, A. M., Ekert, P. G., Pakusch, M., Silke, J., Connolly, L. M., Reid, G. E., et al. (2000). Identification of DIABLO, a mammalian protein that promotes apoptosis by binding to and antagonizing IAP proteins. Cell 102, 43-53. doi: 10.1016/S0092-8674(00)00009-X

Wang, C. Z., Zhang, Z., Anderson, S., and Yuan, C. S. (2014). Natural products and chemotherapeutic agents on cancer: prevention vs. treatment. Am. J. Chin. Med. 42, 1555-1558. doi: 10.1142/S0192415X1420002X

Weiss, L., and Ward, P. M. (1983). Cell detachment and metastasis. Cancer Metastasis Rev. 2, 111-127. doi: 10.1007/BF00048965

Xu, Y., Jiang, Z., Ji, G., and Liu, J. (2010a). Inhibition of bone metastasis from breast carcinoma by rosmarinic acid. Planta Med. 76, 956-962. doi: 10.1055/s-00291240893

Xu, Y., Xu, G., Liu, L., Xu, D., and Liu, J. (2010b). Anti-invasion effect of rosmarinic acid via the extracellular signal-regulated kinase and oxidation-reduction pathway in Ls174-T cells. J. Cell. Biochem. 1, 370-379. doi: 10.1002/jcb.22708 
Yeh, Y. S., Tsai, H. L., Huang, C. W., Wang, J. H., Lin, Y. W., Tang, H. C., et al. (2016). Prospective analysis of UGT1A1 promoter polymorphism for irinotecan dose escalation in metastatic colorectal cancer patients treated with bevacizumab plus FOLFIRI as the first-line setting: study protocol for a randomized controlled trial. Trials 17:46. doi: 10.1186/s13063-0161153-3

Zimmermann, B. F., Walch, S. G., Tinzoh, L. N., Stühlinger, W., and Lachenmeier, D. W. (2011). Rapid UHPLC determination of polyphenols in aqueous infusions of Salvia officinalis L. (sage tea). J. Chromatogr. B Analyt. Technol. Biomed. Life Sci. 15, 2459-2464. doi: 10.1016/j.jchromb.2011.06.038
Conflict of Interest Statement: The authors declare that the research was conducted in the absence of any commercial or financial relationships that could be construed as a potential conflict of interest.

Copyright (๑) 2018 Han, Kee and Hong. This is an open-access article distributed under the terms of the Creative Commons Attribution License (CC BY). The use, distribution or reproduction in other forums is permitted, provided the original author(s) and the copyright owner are credited and that the original publication in this journal is cited, in accordance with accepted academic practice. No use, distribution or reproduction is permitted which does not comply with these terms. 